\title{
DETERMINATION OF ACRYLAMIDE AND HYDROXYMETHYLFURFURAL (HMF) VALUES AS AFFECTED BY FRYING DURATION AND TEMPERATURE LEVELS DURING THE PREPARATION OF TRAY KADAYIF DESSERT
}

\author{
SEYYedCHERAGHI, K. * KotANCILAR, H. G. - KARAOGLU, M. M. \\ Department of Food Engineering, Faculty of Agriculture, Ataturk University \\ 2524, Erzurum, Turkey \\ *Corresponding author \\ e-mail: kimiya.seyyed.cheraghi11@ogr.atauni.edu.tr \\ (Received $12^{\text {th }}$ Nov 2018; accepted $14^{\text {th }}$ Feb 2019)
}

\begin{abstract}
In this study, a wire kadayıf on a tray was fried at 175,200 and $225^{\circ} \mathrm{C}$ for 40,50 and 60 min. The temperature levels affected hydroxymetylfurfural (HMF) content, color values (L, a, b), outward appearance, interior color, taste, texture, aftertaste and general acceptability values at significant levels ( $\mathrm{p}$ $\leq 0.01)$; as well as $\mathrm{pH}$ and aroma ( $\mathrm{p} \leq 0.05)$. As the temperature increases the HMF content, color value a, outward appearance, interior color, taste, odor, aroma, texture, aftertaste and the general acceptability values have increased. Whereas the moisture, $\mathrm{pH}$ and $\mathrm{L}$ color values decreased. The frying time had an effect on moisture. The changes in the color brightness (L), red color (+a), and the yellow color $(+b)$ values of the kadayif were highly significant $(\mathrm{p} \leq 0.01)$; and the changeswere also significant $(\mathrm{p} \leq 0.05)$ on the HMF content, texture, aftertaste and general acceptability values. As the frying time increases HMF content, a color value, texture, aftertaste and the general acceptability values increased whereas the moisture, $\mathrm{L}$ and $\mathrm{b}$ color values decreased.
\end{abstract}

Keywords: acrylamide, $H M F$, frying temperature, frying duration, tray kadaylf

\section{Introduction}

Kadayıf is a delicious Turkish sweet pastry, consumed in different provinces of Turkey such as Mersin, Hatay, Erzurum, Diyarbakir, and Gaziantep. Tray kadayif and creamy kadayif can both be prepared with either whole hazelnut, walnut or pistachio (Anon, 2012). According to the "standard of tray kadaylf" (T.S-10344, 1992), it is a semi-processed product made by adding drinking water to sifted flour and baking it on a plate. However, tray kadayıf is offered in raw and fired varieties in markets. Flour for making Kadayıf should have the following properties: humidity $14.5 \%$ (max), protein 8 $10 \%(\mathrm{~F}=5.70)$, the essence of age $22 \%(\max )$, water holding capacity $54 \%$ ( $\max$ ), stability 2 min $(\max )$, softening temperature $150 \mathrm{BU}(\max )$ and minimum value of the biscuits perchance show maximum level in kadayif. In recent years, tray kadayif has mostly been produced in small enterprises, but has also been manufactured in large quantities to a lower extent (Pekak, 2006).

Acrylamide was first prepared in 1893 by Moureu at $10{ }^{\circ} \mathrm{C}$ on a saturated solution of acrylic chloride in benzene, followed by adding dry ammonia and boiling for mean duration, then ammonium chloride was refluxed by filtrating, cooling, and precipitating acrylamide (Carpenter and Davis, 1957). Neurotoxic effects of acrylamide were detected in a laboratory with animal testing. In addition, genotoxic and carcinogenic effects of acrylamide have been identified in recent years, its presence in many processed foods has been a hazard to human health (Joint, 2005). Acrylamide as a chemical substance was synthesized in 1949, it is white, odorless, crystalline, solid and 
soluble in water (255 g/L of water) (Thomas and Thomas, 2012), its melting and boiling point is $87.5^{\circ} \mathrm{C}$ and $125^{\circ} \mathrm{C}$, respectively (Gölükçü and Tokgöz, 2005). It has no burn inducing or irritating properties, low acidity, and weak basic characters. It has a monomeric structure of two different functional groups; double bond and weak amid group as the electron, and these groups are joined through chemical reactions (Can, 2007). In food items, acrylamide has a simple structure which occurs as a result of reactions taking place among carbohydrates, proteins, amino acids, lipids, or other food components (Gölükçü and Tokgöz, 2005). It is usually formed during frying, baking, and roasting (Svensson et al., 2003). The content of acrylamide in the product can be identified by some factors, such as preparation methods, compositions, ambient temperature, and $\mathrm{pH}$. Asparagine appears to be the primary amino acid involved in the production of acrylamide via the Millard reaction (LoPachin and Canady, 2004).

According to Zyzak et al. (2003), there is a linear relationship between free asparagine contents and forming of acrylamide in the product. Gölükçü and Tokgöz (2005) indicated that asparagine content of the product is the most important factor in the formation of acrylamide in cereals. The duration of heating initiates the Millard reaction, in which sugars (simple monosaccharides capable of carrying out reduction reactions) present in starchy foods are reduced with amino acids to produce acrylamide. Applying high temperature (more than $120^{\circ} \mathrm{C}$ ) caused a raise in the acrylamide contents above $1 \mathrm{mg} / \mathrm{kg}$ in food items with high contents of carbohydrates. Therefore, there is a relationship between acrylamide in the food and temperature. Controlling the temperature range can reduce the amount of acrylamide formation. Food which is prepared through boiling has a low content of this compound, thus it should be preferred to frying, baking, roasting, and grilling; using methods such as frying or roasting at elevated temperatures for a long duration should also be avoided (Gölükçü and Tokgöz, 2005).

Beside acrylamide, hydroxylmethylfurfural (HMF) is another harmful compound which occurs as a result of the Millard reaction in biscuits. HMF is formed from an aromatic alcohol, aromatic aldehyde, and furan ring, and as an intermediate product in the hydrolysis of hexose in an acidic medium or in the Millard reaction (Seyyed Cheraghi, 2014). The concentration of HMF varies significantly and in some food items it can even reach $1 \mathrm{~g} / \mathrm{Kg}$ (Rada-Mendoza et al., 2004; Akkan et al., 2001). The formation and amount of $\mathrm{HMF}$ are affected by temperature and $\mathrm{pH}$ value, also the quality deterioration of a wide range of edibles is determined by Hydroxymethylfurfural (HMF) (Gökmen and Şenyuva, 2006). Beside the harmful compounds which are the result of Maillard reactions, antioxidant compounds are also formed (Yildırım, 2010). Some researchers have stated that HMF has possibly genotoxic and mutagenic effects on human cells, possibly inducing liver and colon cancer (Svendsen et al., 2007; Monien et al., 2012; Zhang and An, 2017); so the objective of this study was to determine the effect of temperature and duration on acrylamide and hydroxymethylfurfural formation during the preparation of tray kadayif.

\section{Material}

As the ingredients of tray kadayıf, butter and hazelnut were acquired in the markets (Erzurum, Turkey). The ratio of grout which has been used was 2:1 sugar mixed with water. After boiling, approximately $(2.0 \mathrm{ml})$ lemon juice was added to prevent 
crystallization. The tray kadayif had the following values: $\mathrm{pH}=6.43$, humidity $=20.53 \%, \mathrm{~L}(96.19),+\mathrm{a}(0.53)$ and $+\mathrm{b}(16.89)$.

\section{Method}

\section{Processing of tray kadaylf}

$200 \mathrm{~g}$ of butter was melted on a very low temperature and was then mixed with the kadayıf for a 4-5 min period; and about $500 \mathrm{~g}$ was laid with a homogeneous thickness. After seating on the tray, a special medium-density fiberboard (MDF) wood and an overall $10 \mathrm{~kg}$ heavy weight was placed on it. The tray kadayıf was fried at $175^{\circ} \mathrm{C}$, $200{ }^{\circ} \mathrm{C}$ and $225^{\circ} \mathrm{C}$ for $40,50,60$ min respectively. After that, the previously prepared syrup was poured onto it; then sliced and crushed nuts were placed on top, and was then presented to panelists. The analysis samples were prepared from the upper part of the fried tray kadayif samples after grounding it into very small pieces.

\section{The analyses performed on tray kadaylf samples}

\section{Measurement of the color intensity}

In the above-mentioned samples, the color densities, which are brightness of kadaylf color (L; 0-100: dark-bright) red color $(+a)$, yellow color $(+b)$ were measured using three parallel Minolta Colorimeter device. Results were evaluated according to the International Commission on Illumination (CIE Lab, Commission Internationale de l'Eclairage; Anonymous, 2012).

\section{Acrylamide analysis}

The analysis of acrylamide was performed according to Robarge et al. (2003). During the preparation of the sample the following steps were taken.

The acrylamide standard solutions, used as the sample calibration solutions were $1000 \mathrm{ppb}, 500 \mathrm{ppb}$, and $50 \mathrm{ppb} 100 \mathrm{ppb}$, and were subjected to the same processes to obtain a calibration curve.

Extraction: very small particles of tray kadayıf samples $(1 \mathrm{~g})$ were put into $10 \mathrm{ml}$ demineralized water in a $50 \mathrm{ml}$ Erlenmeyer, then was magnetically stirred for $20 \mathrm{~min}$, at $5500 \mathrm{rpm}$ and centrifuged for about $10 \mathrm{~min}$. After centrifuging the supernatant, it was filtrated through a $0.45 \mu \mathrm{m}$ nylon filter, then $200-300 \mu \mathrm{L} 0.1$ normality $(\mathrm{N})$ potassium bromate $\left(\mathrm{KBrO}_{3}\right)$ was slowly added to $3 \mathrm{ml}$ of the filtrate, followed by stirring and 1 hour of rest in an ice bath. The ice bathing tubes received one drop of $1.0 \mathrm{~N}$ sodium thiosulfate $\left(\mathrm{Na}_{2} \mathrm{O}_{3} \mathrm{~S}_{2}\right)$ and were mixed slowly with, followed by adding $2 \mathrm{ml}$ of ethyl acetate $\left(\mathrm{C}_{4} \mathrm{H}_{8} \mathrm{O}_{2}\right)$. The tubes which had Ethyl acetate added were centrifuged at 5500 rpm for an additional $10 \mathrm{~min}$, then the vials were transferred for supernatant analysis.

Sample extracts and the standard solution were measured using a Gas Chromatography-Mass Spectrometry (GC-MS, Agilent) analysis device. Positron effect was analyzed with imaging method of the GC-MS, DB-225 column $(30 \mathrm{~m} \times 0.25 \mathrm{~mm} \times$ $0.25 \mu \mathrm{m})$ and helium gas. The oven temperature was increased from 40 to $200{ }^{\circ} \mathrm{C}$ and in this analysis set which increasing $30{ }^{\circ} \mathrm{C}$ in a minute split-less mode is used. 


\section{Sensory analysis}

The sensory analysis of tray kadayif was carried out at the laboratory of the Faculty of Agriculture, Food Engineering Department, Ataturk University, and panelists were selected from among the graduate and postgraduate students of the Food Engineering Department faculty. Slides which were cut from each tray kadayıf were served on coded plastic plates with drinking water to eight panelists, who were asked to evaluate them. The tray kadayıf was left waiting for $24 \mathrm{~h}$ at room temperature. Tray kadayıf samples' taste, aroma, color, texture and overall acceptability were subjected to evaluation. There was a 9-point hedonic scale for the evaluation of these parameters $(1=$ very bad, $9=$ very good) for the panelists to rate each tray kadayif (Kramer and Twigg, 1973).

\section{Determination of hydroxymethylfurfural (HMF)}

Hydroxymethylfurfural analysis was performed with a High-Performance Liquid Chromatography (HPLC) on samples prepared according to the method given by RadaMendoza et al. (2002). According to the aforementioned method, a $2 \mathrm{~g}$ sample was transferred to a $50 \mathrm{ml}$ Erlenmeyer, to which $4 \mathrm{ml}$ each of carrez I [15 g potassium hexacyanoferrate (II) trihydrate $\left(\mathrm{K}_{4}\left[\mathrm{Fe}(\mathrm{CN})_{6}\right] \times 3 \mathrm{H}_{2} \mathrm{O}\right)$ mixed with $100 \mathrm{ml}$ ultra-pure water] and carrez II [30 g zinc sulfate heptahydrate $\left(\mathrm{ZnSO}_{4} \times 7 \mathrm{H}_{2} \mathrm{O}\right)$ mixed with $100 \mathrm{ml}$ ultra-pure water] were added and flask was filled to $50 \mathrm{~mL}$ with deionized water. After stirring for $30 \mathrm{~min}$, the contents of the Erlenmeyer were passed through a $0.45 \mu \mathrm{m}$ filter. The samples were analyzed using the HPLC, Agilent 1100 system. UV-VIS detector and Nucleosil 5C18 (250 × 4,6 mm) column (Hichrom, Reading Berkshire, England) were used in this system. The samples were then placed at room temperature, and 10:90 $(\mathrm{v} / \mathrm{v})$ methanol-water was used with a flow rate of $1 \mathrm{ml} / \mathrm{min}$ to keep it mobile. Hydroxymethylfurfural concentration curve was measured using external calibration (55690-5-HMF, Fluka Chemika) at $280 \mathrm{~nm}$.

\section{Determination of $p H$}

The homogenized $3 \mathrm{~g}$ tray kadayif sample was placed into pure water and its $\mathrm{pH}$ was assessed. The sample's $\mathrm{pH}$ was previously measured to be $\mathrm{pH} 4.00$ and $\mathrm{pH} 7.00$ using an INOLAB pH 720 brand of Microprocessor (Torley et al., 2008).

\section{Determination of dry matter}

Homogenous samples of about 8-10 g were taken from the total samples of both acrylamide and $\mathrm{HMF}$ and then dried in a drying oven at $110{ }^{\circ} \mathrm{C}$ until a constant weight was achieved (Kotanc1lar, 2013).

\section{Experimental plan}

Trials were conducted with factorial arrangement by three different frying temperatures $\left(175,200\right.$ and $\left.275^{\circ} \mathrm{C}\right)$ and three different frying durations (40, 50 and $60 \mathrm{~min})$ in complete randomized design $(\mathrm{CRD})$ with two replicates $(3 \times 3 \times 2)$.

\section{Statistical analysis}

The raw values received from trials were subjected to variance analysis in SPSS (SPSS1999), and the mean of the sources of the main variation has been found 
important, as compared with Duncan Multiple Comparison Test (Y1ldiz and Bircan, 2003).

\section{Results and discussion}

\section{Acrylamide values in tray kadaylf}

In the present study, variance analysis (Table 1) indicated that there were significant $(\mathrm{p} \leq 0.01)$ differences among different temperatures and different durations based on acrylamide values. As shown in Table 2, the temperature increase does not cause any significant changes on the acrylamide content, as the lowest amount of acrylamide was $(130.5 \mu \mathrm{g} / \mathrm{kg})$ at $200{ }^{\circ} \mathrm{C}$, and the highest amount was $(137.7 \mu \mathrm{g} / \mathrm{kg})$ at $175^{\circ} \mathrm{C}$. Mottram et al. (2002) determinate that in the asparagine/glucose model systems the increase of temperature from $120{ }^{\circ} \mathrm{C}$ to $170{ }^{\circ} \mathrm{C}$ increases the amount of acrylamide and above $170{ }^{\circ} \mathrm{C}$ it is reduced. The acrylamide content increases with the frying duration. The lowest amount of acrylamide $(132 \mu \mathrm{g} / \mathrm{kg})$ was determined after $40 \mathrm{~min}$ and the highest amount $(137 \mu \mathrm{g} / \mathrm{kg})$ was obtained with $60 \mathrm{~min}$ of duration. Tuta (2009) stated that if the temperature rises above $100{ }^{\circ} \mathrm{C}$ and the duration of frying increases in parallel, then the acrylamide content decreases. The highest value was achieved with a high-temperature heat treatment of low duration.

Table 1. Variance analysis of acrylamide, $L,+a,+b$ color values at different temperatures and duration

\begin{tabular}{c|c|c|c|c|c}
\hline \multirow{2}{*}{ SOV } & \multirow{2}{*}{ SD } & \multicolumn{3}{|c}{ F } \\
\cline { 3 - 5 } & & Acrylamide & $\mathbf{L}$ & $\mathbf{+ a}$ & $\mathbf{+ b}$ \\
\hline Frying temperature $\left({ }^{\circ} \mathrm{C}\right)$ & 2 & 2.54 & $410.00^{* *}$ & $12810.00^{* *}$ & $3184.00^{* *}$ \\
Frying duration $(\mathrm{S})$ & 2 & 1.06 & $120.00^{* *}$ & $3253.00^{* *}$ & $976.00^{* *}$ \\
$\mathrm{C} \times \mathrm{S}$ & 4 & 1.29 & $20.00^{* *}$ & $59.00^{* *}$ & $1467.00^{* *}$ \\
Error & 9 & & & \\
\hline
\end{tabular}

$*$ **: Significant at $\mathrm{p} \leq 0.05$ and $\mathrm{p} \leq 0.01$, respectively

Table 2. Mean comparison of acrylamide, $L,+a,+b$ color values at different temperatures and duration

\begin{tabular}{c|c|c|c|c|c}
\hline \multirow{2}{*}{ Frying temperature $\left({ }^{\circ} \mathbf{C}\right)$} & \multirow{2}{*}{$\mathbf{n}$} & \multicolumn{4}{|c}{ Means } \\
\cline { 3 - 6 } & & Acrylamide $(\boldsymbol{\mu g} / \mathbf{k g})$ & $\mathbf{L}$ & $\mathbf{+ a}$ & $\mathbf{+ b}$ \\
\hline 175 & 6 & $137.70 \mathrm{a} *$ & $66.67 \mathrm{a}$ & $2.72 \mathrm{c}$ & $25.10 \mathrm{~b}$ \\
200 & 6 & $130.50 \mathrm{a}$ & $60.16 \mathrm{~b}$ & $7.81 \mathrm{~b}$ & $26.77 \mathrm{a}$ \\
225 & 6 & $135.10 \mathrm{a}$ & $45.05 \mathrm{c}$ & $13.52 \mathrm{a}$ & $15.81 \mathrm{a}$ \\
\hline Std. error & $\mathbf{5}$ & \pm 0.547 & \pm 0.048 & \pm 0.105 \\
\hline Frying duration $(\mathbf{S})$ & $\mathbf{n}$ & 6.3 & $63.36 \mathrm{a}$ & $5.45 \mathrm{c}$ & $25.44 \mathrm{a}$ \\
\hline 50 & 6 & $132.00 \mathrm{a}$ & $57.16 \mathrm{~b}$ & $7.72 \mathrm{~b}$ & $23.23 \mathrm{~b}$ \\
60 & 6 & $134.00 \mathrm{a}$ & $51.36 \mathrm{c}$ & $10.87 \mathrm{a}$ & $19.01 \mathrm{c}$ \\
\hline Std. error & 6 & $137.00 \mathrm{a}$ & \pm 0.547 & \pm 0.048 & \pm 0.105 \\
\hline
\end{tabular}

*The average shown with the same letters are statistically indistinguishable from each other $(\mathrm{p}<0.05)$ 


\section{Color parameter's values of the tray kadaylf}

Variance analysis (Table 1) of the tray kadayıf L (Brightness), $+\mathrm{a}$ (Redness), and $+\mathrm{b}$ (Yellowness) color values influenced by the frying temperature, duration and $\mathrm{C} \times \mathrm{S}$ interactions was highly significant $(\mathrm{p} \leq 0.01)$. The important variables of the frying temperature and duration including $\mathrm{L},+\mathrm{a}$, and $+\mathrm{b}$ color values can be found in Table 2 . The lowest amount of $\mathrm{L}$ color value (45.05) was assessed at $225^{\circ} \mathrm{C}$ and the maximum amount (66.67) was obtained at $175^{\circ} \mathrm{C}$ temperature. By increasing the duration of frying, L color values decreased. The lowest L color value (51.36) was measured after the $60 \mathrm{~min}$ mark and the maximum amount (63.36) was obtained after $40 \mathrm{~min}$ of duration. The lowest amount of $+\mathrm{a}$ color value (2.72) was detected at $175^{\circ} \mathrm{C}$ and the maximum amount (13.52) was obtained at $225{ }^{\circ} \mathrm{C}$ temperature. By increasing the frying duration, +a color value would increase. The lowest amount of + a color value (5.45) was assessed after $40 \mathrm{~min}$ and the highest amount (10.87) was obtained at the $60 \mathrm{~min}$ mark. The lowest amount of $\mathrm{b}$ color value $(15.81)$ was measured at $225^{\circ} \mathrm{C}$ and the highest amount (26.77) was obtained at $200{ }^{\circ} \mathrm{C}$ temperature. By increasing the frying duration, b color values decreased. The lowest amount of b color value (19.01) was detected after 60 min and the maximum amount (25.44) was obtained during the $40 \mathrm{~min}$ duration. The interaction between $\mathrm{C}$ and $\mathrm{S}$, and its effect on $\mathrm{L},+\mathrm{a}$, and $+\mathrm{b}$ color values are given in Table 1.

The result showed that the reduction in the L color value as a result of the increased temperature caused the tray kadayif to gain a dark color. In parallel, +a surface color value has increased and has become more of a reddish color, while in $+b$ value there was an increase at first, followed by a serious decline. While o the dark and intense red color was obtained at $225^{\circ} \mathrm{C}$ the brightest and least red surface color was obtained at $175^{\circ} \mathrm{C}$. Colored compounds formed as a result of Maillard reaction are high molecular weight macromolecules called Melanoidins and low molecular weight molecules which have two or three heterocyclic rings (Ames et al., 1998). Color formation, temperature, duration, increase with $\mathrm{pH}$ and moisture content in the medium ( $\mathrm{aw}=0.3-0.7$ ). As shown in Table 2, with the increase in temperature and duration caused a decrease in the $\mathrm{L}$ value of tray kadayif, which means the surface color got darker. In parallel, the increase in a value was observed, which means that the intensity of red increased. The brightest and pinkish colors were obtained when the tray kadayıf was fried for $40 \mathrm{~min}$ and the darkest red was obtained by frying for $60 \mathrm{~min}$. By increasing frying duration $b$ color value decreased. A decrease was observed in yellow color as well. In a study by Özkaynak (2006) each of the three oil varieties developed darker colors depending on the frying duration as a result of variations in the formation of acrylamide, and $\mathrm{L}$ was found to decrease.

\section{Sensory analysis values of tray kadaytf}

Variance analysis values of appearance, interior color, taste, odor, flavor, texture, aftertaste and overall acceptability are shown in Table 3. The effect of frying temperature on appearance, interior color, taste, texture, aftertaste and the overall acceptability of tray kadayıf was statistically highly significant $(\mathrm{p} \leq 0.01)$ whereas that on the aroma and smell was significant at a different level $(\mathrm{p} \leq 0.05)$. The frying duration's effect on the overall acceptability was highly significant $(\mathrm{p} \leq 0.01)$; on the texture and aftertaste it was significant $(\mathrm{p} \leq 0.05)$ while on the appearance, interior color, test, smell and aroma it was not significant. The effect of the interaction between 
frying temperature and frying duration on the outward appearance of tray kadayif, taste, texture, aftertaste and the general acceptability was highly significant $(\mathrm{p} \leq 0.01)$, while that on smell value was significant $(\mathrm{p} \leq 0.05)$ and was not significant on the interior color and the aroma. Significance values of frying temperature can be seen in Table 3, while the Duncan multiple comparison test results are shown in Table 4.

Table 3. Variance analysis of tray kadaylf features at different temperatures and durations

\begin{tabular}{|c|c|c|c|c|c|c|c|c|c|}
\hline \multirow[b]{2}{*}{ S.O.V } & \multirow[b]{2}{*}{ SD } & \multicolumn{8}{|c|}{$\mathbf{F}$} \\
\hline & & Appearance & $\begin{array}{l}\text { Interior } \\
\text { color }\end{array}$ & Taste & Smell & Aroma & Texture & Aftertaste & $\begin{array}{c}\text { General } \\
\text { acceptability }\end{array}$ \\
\hline $\begin{array}{c}\text { Frying } \\
\text { temperature }\left({ }^{\circ} \mathrm{C}\right)\end{array}$ & 2 & $82.08 * *$ & $41.17 * *$ & $8.08 * *$ & $3.56^{*}$ & $4.77^{*}$ & $39.56 * *$ & $15.13^{* *}$ & $12.99 * *$ \\
\hline $\begin{array}{l}\text { Frying duration } \\
\text { (S) }\end{array}$ & 2 & 1.25 & 3.33 & 1.47 & 0.22 & 1.90 & $4.27^{*}$ & $4.72 *$ & $3.51 * *$ \\
\hline $\mathrm{C} \times \mathrm{S}$ & 4 & $13.40 * *$ & 2.71 & $8.00 * *$ & $3.93 *$ & 1.60 & $7.76^{* *}$ & $7.99 * *$ & $9.75 * *$ \\
\hline Error & 9 & & & & & & & & \\
\hline
\end{tabular}

$*, * *$ : Significant at $\mathrm{p} \leq 0.05$ and $\mathrm{p} \leq 0.01$, respectively

Table 4. Mean comparison of tray kadaylf features at different temperatures and durations

\begin{tabular}{|c|c|c|c|c|c|c|c|c|c|}
\hline \multirow{2}{*}{$\begin{array}{c}\text { Frying } \\
\text { temperature }\left({ }^{\circ} \mathbf{C}\right)\end{array}$} & \multirow[b]{2}{*}{$\mathbf{n}$} & \multicolumn{8}{|c|}{ Means } \\
\hline & & Appearance & $\begin{array}{c}\text { Interior } \\
\text { color }\end{array}$ & Taste & Smell & Aroma & Texture & Aftertaste & $\begin{array}{c}\text { General } \\
\text { acceptability }\end{array}$ \\
\hline 175 & 6 & $2.83 \mathrm{c}$ & $3.79 \mathrm{c}$ & $4.87 \mathrm{~b}$ & $5.21 \mathrm{~b}$ & $4.67 \mathrm{~b}$ & $4.33 \mathrm{c}$ & $4.38 \mathrm{~b}$ & $4.50 \mathrm{~b}$ \\
\hline 200 & 6 & $5.96 \mathrm{~b}$ & $6.08 \mathrm{~b}$ & $5.87 \mathrm{a}$ & $5.96 \mathrm{ab}$ & $5.88 \mathrm{a}$ & $5.67 \mathrm{~b}$ & $5.79 \mathrm{a}$ & $5.96 \mathrm{a}$ \\
\hline 225 & 6 & $7.00 \mathrm{a}$ & $7.54 \mathrm{a}$ & $6.21 \mathrm{a}$ & $6.25 \mathrm{a}$ & $6.04 \mathrm{a}$ & $6.75 \mathrm{a}$ & $6.17 \mathrm{a}$ & $6.04 \mathrm{a}$ \\
\hline \multicolumn{2}{|l|}{ Std. error } & \pm 0.24 & \pm 0.29 & \pm 0.24 & \pm 0.34 & \pm 0.34 & \pm 0.19 & \pm 0.24 & \pm 0.24 \\
\hline $\begin{array}{l}\text { Frying duration } \\
(\text { min) }\end{array}$ & $\mathbf{n}$ & & & & & & & & \\
\hline 40 & 6 & $5.00 \mathrm{a}$ & $5.63 \mathrm{a}$ & $5.30 \mathrm{a}$ & $5.58 \mathrm{a}$ & $5.00 \mathrm{a}$ & $5.16 \mathrm{~b}$ & $4.87 \mathrm{~b}$ & $5.00 \mathrm{~b}$ \\
\hline 50 & 6 & $5.58 \mathrm{a}$ & $5.68 \mathrm{a}$ & $5.70 \mathrm{a}$ & $5.89 \mathrm{a}$ & $5.67 \mathrm{a}$ & $5.62 \mathrm{ab}$ & $5.54 \mathrm{ab}$ & $5.62 \mathrm{ab}$ \\
\hline 60 & 6 & $5.18 \mathrm{a}$ & $5.79 \mathrm{a}$ & $5.95 \mathrm{a}$ & $5.93 \mathrm{a}$ & $5.92 \mathrm{a}$ & $5.96 \mathrm{a}$ & $5.91 \mathrm{a}$ & 5.87- a \\
\hline \multicolumn{2}{|l|}{ Std. error } & \pm 0.24 & \pm 0.29 & \pm 0.24 & \pm 0.34 & \pm 0.34 & \pm 0.19 & \pm 0.24 & \pm 0.24 \\
\hline
\end{tabular}

*The average shown with the same letter are statistically indistinguishable from each other $(\mathrm{p}<0.05)$

As shown in Table 4, increase in the temperature of tray kadayıf influenced the appearance, interior color, taste, odor, flavor, texture, and aftertaste positively and was also more appreciated by panelists. While the highest values of appearance, interior color, taste, odor, flavor, texture, aftertaste and general accessibility were obtained at $225^{\circ} \mathrm{C}$, the least admired was the tray kadayıf fried in $175^{\circ} \mathrm{C}$.

\section{HMF, $p H$, and surface moisture values of tray kadaylf}

Variance analysis of HMF, $\mathrm{pH}$ and the surface moisture under different frying temperatures and durations of tray can be seen in Table 5. As shown in Table 5 the effect of frying temperature on HMF and humidity values was highly significant ( $\mathrm{p} \leq$ $0.01)$, while on $\mathrm{pH}$ value was significant $(\mathrm{p} \leq 0.05)$. The effect of frying duration on humidity values was highly significant $(\mathrm{p} \leq 0.01)$ while on HMF values was significant 
$(\mathrm{p} \leq 0.05)$. As shown in Table 6, the increase in the temperature caused an increase in $\mathrm{HMF}$ values (the lowest value of HMF was achieved at $175^{\circ} \mathrm{C}$, while the highest value was observed at $225^{\circ} \mathrm{C}$ ), and a decrease in $\mathrm{pH}$ and the amount of humidity on the surface. Depending on the increase in the temperature the moisture content decreased accordingly. Normal moisture content in particular decreased at temperatures above $50{ }^{\circ} \mathrm{C}$ and $\mathrm{pH}$ 4-7, while $\mathrm{HMF}$ formation rate increased (Borrelli et al., 2002; Oral, 2011).

Table 5. Variance analysis of $H M F, P H$ and humidity values under different temperatures and durations

\begin{tabular}{c|c|c|c|c}
\hline \multirow{2}{*}{ S.O.V } & \multirow{2}{*}{ SD } & \multicolumn{3}{|c}{ F } \\
\cline { 3 - 5 } & & HMF & pH & Humidity \\
\hline Frying temperature (C) & 2 & $14.34^{* *}$ & $5.59^{*}$ & $239.00^{* *}$ \\
Frying duration (S) & 2 & $2.89^{*}$ & 2.22 & $108.00^{* *}$ \\
C $\times$ S & 4 & 1.40 & 0.64 & $24.00^{* *}$ \\
Error & 9 & & & \\
\hline
\end{tabular}

*. **: Significant at $\mathrm{p} \leq 0.05$ and $\mathrm{p} \leq 0.01$, respectively

Table 6. Mean comparison of HMF, PH and humidity values under different temperatures and durations

\begin{tabular}{|c|c|c|c|c|}
\hline \multirow{2}{*}{ Frying temperature $\left({ }^{\circ} \mathrm{C}\right)$} & \multirow{2}{*}{$\mathbf{n}$} & \multicolumn{3}{|c|}{ Mean } \\
\hline & & HMF $(\mu \mathrm{g} / \mathrm{kg})$ & pH & Humidity (\%) \\
\hline 175 & 6 & $8.70 \mathrm{~b}$ & $5.70 \mathrm{a}$ & $2.29 \mathrm{a}$ \\
\hline 200 & 6 & $54.30 \mathrm{~b}$ & $5.60 \mathrm{~b}$ & $0.78 \mathrm{~b}$ \\
\hline 225 & 6 & $342.90 \mathrm{a}$ & $5.50 \mathrm{~b}$ & $0.56 \mathrm{c}$ \\
\hline \multicolumn{2}{|l|}{ Std. error } & \pm 47.8 & \pm 0.1 & \pm 0.1 \\
\hline Frying duration (min) & $\mathbf{n}$ & & & \\
\hline 40 & 6 & $53.00 \mathrm{~b}$ & $5.68 \mathrm{a}$ & $1.87 \mathrm{a}$ \\
\hline 50 & 6 & $135.00 \mathrm{ab}$ & $5.61 \mathrm{a}$ & $1.16 \mathrm{~b}$ \\
\hline 60 & 6 & $216.00 \mathrm{a}$ & $5.52 \mathrm{a}$ & $0.61 \mathrm{c}$ \\
\hline \multicolumn{2}{|l|}{ Std. error } & \pm 47.8 & \pm 0.1 & \pm 0.1 \\
\hline
\end{tabular}

*The averages shown with the same letters are statistically indistinguishable from each other $(\mathrm{p}<0.05)$

The increasing in frying duration lead to a $\mathrm{pH}$ decrease. However, this change was not statistically significant. The HMF value proved to be dependent on frying duration. The lowest HMF value was measured during the 40 min frying period, while the highest value was detected after the 60 min cooking (Table 6). Cooking duration in the production of dry fruit pulp is extremely important. The determination of HMF and acrylamide contents significantly increased with the increase in cooking duration (Boz, 2012). As a result of the increase of frying duration, moisture content decreased. Elmore et al. (2005) investigated how much the moisture content depends on frying duration of baked cakes of rye and wheat flour and potatoes. The moisture contents of potatoes and cakes made from rye and wheat flour in the first minute were 59.73, 41.60, and 39.60, respectively. With the 10 min duration, the ratio under $180^{\circ} \mathrm{C}$ decreased to $24.25,3.86$, 
and 10.33. After $50 \mathrm{~min}$, it decreased to $0.75,0.70$, and 0 (Elmore et al., 2005). The reduction was observed in the moisture content when the temperature of tray kadayif was increasing.

As displayed in Table 6, with the increase of temperature, at the end of all three periods there was an increase in moisture content of tray kadayıfs. At $175^{\circ} \mathrm{C}, 200{ }^{\circ} \mathrm{C}$ and $225^{\circ} \mathrm{C}$ and with $40 \mathrm{~min}$ of frying duration the highest moisture content, but after $60 \mathrm{~min}$ it reached the lowest value. These properties were observed after the 50 and 60 min periods. When the temperature was raised from $175^{\circ} \mathrm{C}$ to $200{ }^{\circ} \mathrm{C}$, there was a rapid decrease in the moisture content. At $220^{\circ} \mathrm{C}$ and $40 \mathrm{~min}$ of frying, there were not many changes to moisture content.

\section{Conclusions}

None of the factors has a statistically significant effect on the value of acrylamide. Increase in temperature does not cause any change on acrylamide content. While raising frying duration caused an increase. Increase in temperature levels of tray kadayif reduced its $L$ color value and a darker color was obtained.

The increase in temperature levels, caused an increase in HMF values, a decrease in $\mathrm{pH}$ and moisture content on the surface. Depending on the temperature rise a reduction in moisture content was observed. Increasing the frying duration caused an increase in $\mathrm{pH}$ values. Depending on higher temperature levels and longer frying duration, HMF values raised. With the increase of frying duration, the moisture content was reduced.

In this research, $a$ color value of the surface increased and the kadayif appeared much redder. In $b$ color value there was an increase at first and then it had a serious decrease. Raising frying duration caused a decrease in $L$ color value of tray kadayif, which means that the surface color got darker. In parallel, an increase in the $a$ color value was observed, which meant a more intensive red color. The $b$ color value decreased by increasing frying duration. An increase in temperature levels had positively influenced the appearance, interior color, taste and smell and caused it to be appreciated by panelists. Increasing the duration of frying had no effect on the aroma of tray kadayif and had a positive effect on texture, aftertaste and general acceptability.

Acknowledgements. This research was supported by The Research Fund of Ataturk University, Erzurum, Turkey, contract no. BAP-2012.

\section{REFERENCES}

[1] Akkan, A. A., Özdemir, Y., Ekiz, H. L. (2001): Derivative spectrophotometric determination of 5-(hydroxymethyl)-2-furaldehyde (HMF) and furfural in locust bean extract. - Molecular Nutrition \& Food Research 45(1): 43-46.

[2] Ames, J. M., Bailey, R. G., Mann, J. (1998): Recent Advances in the Analysis of Coloured Maillard Reaction Products. - In: O'Brien, J. et al. (eds.) The Maillard Reaction in Foods and Medicine. Woodhead, Sawston, UK, pp. 76-81.

[3] Anon (2012): MEGEP. Kadayıf Çeşitleri. - T. C. Milli Eğitim Bakanlığı, Ankara (in Turkish).

[4] Anonymous (2012): CIE Lab, Commission Internationale de l'Eclairage. www.cie.co.at/publications/colorimetry-part-3-cie-tristimulus-values. 
[5] Borrelli, R. C., Visconti, A., Mennella, C., Anese, M., Fogliano, V. (2002): Chemical characterization and antioxidant properties of coffee melanoidins. - Journal of Agricultural and Food Chemistry. 50(22): 6527-6533.

[6] Boz, H. (2012): Dut pestilinin kimyasal, dokusal ve duyusal özelliklerine buğday unu, sakkaroz şurubu, glikoz şurubu ve pişirme süresinin etkileri. - PHD Thesis, Atatürk Üniversitesi, Erzurum (in Turkish).

[7] Can, N. Ö. (2007): Akrilamidin gida maddelerinde oluşumuna etki eden faktörlerin incelenmesi ve miktarinin tayini. - PHD Thesis. Anadolu Üniversitesi Sağllk Bilimleri Enstitüsü Anabilim Dalı Analitik Kimya, Eskişehir (in Turkish).

[8] Carpenter, E. L., Davis, H. S. (1957): Acrylamide. Its preparation and properties. Journal of Chemical Technology and Biotechnology 7(12): 671-676.

[9] Degen, J., Hellwig, M., Henle, T. (2012): 1, 2-Dicarbonyl compounds in commonly consumed foods. - Journal of agricultural and food chemistry 60(28): 7071-7079.

[10] Elmore, J. S., Koutsidis, G., Dodson, A. T., Mottram, D. S., Wedzicha, B. L. (2005): Measurement of acrylamide and its precursors in potato, wheat, and rye model systems. Journal of Agricultural and Food Chemistry 53(4): 1286-1293.

[11] Gökmen, V., Şenyuva, H. Z. (2006): Improved method for the determination of hydroxymethylfurfural in baby foods using liquid chromatography- mass spectrometry. Journal of Agricultural and Food Chemistry 54(8): 2845-2849.

[12] Gölükçü, M., Tokgöz, H. (2005): Gidalarda akrilamid oluşum mekanizmasi ve insan sağliği üzerine etkileri. - Derim 22(1): 41-48.

[13] Joint, F. A. O. (2005): Summary and Conclusions. - Sixty-Fourth Meeting of the Joint FAO/WHO Experts Committee on Food Additives, Rome, 8-17, February 2005, JECFA/64/SC.

[14] Kotancilar, H. G. (2013): Labratuar teknikleri ve enstrümental analiz uygulama kılavuzu. - Atatürk Üniversitesi, Ziraat Fakültesi Ders Yayınları (in Turkish).

[15] Kramer, A., Twigg, B. A. (1973): Quality Control for the Food Industry. Vol. 2. Applications. 3rd Ed. - AVI, Westport, CT.

[16] LoPachin, R. M., Canady, R. A. (2004): Acrylamide toxicities and food safety: session IV summary and research needs. - Neurotoxicology 25(4): 507-509.

[17] Mottram, D. S., Wedzicha, B. L., Dodson, A. T. (2002): Food chemistry: acrylamide is formed in the Maillard reaction. - Nature 419(6906): 448.

[18] Monien, B. H., Engst, W., Barknowitz, G., Seidel, A., Glatt, H. (2012): Mutagenicity of 5-hydroxymethylfurfural in V79 cells expressing human SULT1A1: identification and mass spectrometric quantification of DNA adducts formed. - Chemical Research in Toxicology 25(7): 1484-1492.

[19] Oral, R. A. (2011): Bitkisel kaynaklı fenolik bileşiklerin üretilmesi, bazı fenolik bileşiklerin ve ekstraktların maillard reaksiyon ürünleri üzerine etkilerininin icelenmesi. PHD Thesis, Erciyes Üniversitesi Fen Bilimleri Enstitüsü Gıda Mühendisliği Anabilim Dal, Kayseri (in Turkish).

[20] Özkaynak, E. (2006): Çeşitli pişirme tekniklerinin sigara böreğinde akrilamid oluşumu üzerine etkileri. - Master Thesis, Ege Üniversitesi Fen Bilimleri Enstitüsü, İzmir (in Turkish).

[21] Pekak, R. (2006): Bir ticari değirmende kadayıf lık un üretiminin optimizasyonu üzerine bir çalışma. - Doctoral Dissertation, Selçuk Üniversitesi Fen Bilimleri Enstitüsü.

[22] Rada-Mendoza, M., Olano, A., Villamiel, M. (2002): Determination of hydroxymethylfurfural in commercial jams and in fruit-based infant foods. - Food Chemistry 79(4): 513-516.

[23] Rada-Mendoza, M., Sanz, M. L., Olano, A., Villamiel, M. (2004): Formation of hydroxymethylfurfural and furosine during the storage of jams and fruit-based infant foods. - Food Chemistry 85(4): 605-609.

[24] Robarge, T., Phillips, E., Conoley, M. (2003): Analysis of Acrylamide in Food by GC/MS. - LC GC, North America. 
[25] Seyyedcheraghi, K. (2014): Tepsi kadayıf tatlısının HMF ve akrilamid miktarı üzerine kızartma sıcaklığı ve sürenin etkisi. - Master Thesis, Atatürk Üniversitesi Fen Bilimleri Enstitüsü Gıda Mühendisliği Anabilim Dalı, Erzurum (in Turkish).

[26] Svendsen, C., Husøy, T., Glatt, H., Haugen, M., Alexander, J. (2007): 5Sulfooxymethylfurfural (SMF), the metabolite of 5-hydroxymethylfurfural (HMF), increases the numbers of adenoma and aberrant crypt foci in the intestine of min-mice. Toxicology Letters 172: S202.

[27] Svensson, K., Abramsson, L., Becker, W., Glynn, A., Hellenäs, K. E., Lind, Y., Rosen, J. (2003): Dietary intake of acrylamide in Sweden. - Food and Chemical Toxicology 41(11): 1581-1586.

[28] T.S-10344. (1992): Tel kadayıf. türk standartları enstitüsü. - Necatibey Cad. No: 112, Bakanlıklar, Ankara, Turkey (Turkish Standard).

[29] Thomas, A., Thomas, A. (2012): Acrylamide - a potent carcinogen in food. International Journal of Science and Research (IJSR) 2(7): 177-180.

[30] Torley, P. J., De Boer, J., Bhandari, B. R., Kasapis, S., Shrinivas, P., Jiang, B. (2008): Application of the synthetic polymer approach to the glass transition of fruit leathers. Journal of Food Engineering 86(2): 243-250.

[31] Tuta, S. (2009): Dondurulmuş patates dilimlerine uygulanan mikrodalga ile ön çözdürme işleminin parmak Patatesin akrilamid içeriği ve kalite özellikleri Üzerine etkisi. - Master Thesis, Gıda Mühendisliği Ana bilim dalı, Mersin üniversitesi Fen Bilimleri Enstitüsü, Mersin (in Turkish).

[32] Yıldırım, A. (2010): Amino asit zenginlestirmesinin bisküvi ve benzeri ürünlerde akrilamid olusumuna etkisi. - Master Thesis, Gıda Mühendisliği Anabilim Dalı, Hacettepe Üniversitesi, Ankara (in Turkish).

[33] Yıldız, N., Bircan, H. (2003): Araştırma ve deneme metotları. - Atatürk Üniversitesi, Ziraat Fakültesi Yayınları Yayın Erzurum (in Turkish).

[34] Zhang, Y., An, X. (2017): Inhibitory mechanism of quercetin against the formation of 5(hydroxymethyl)-2-furaldehyde in buckwheat flour bread by ultra-performance liquid chromatography coupled with high-resolution tandem mass spectrometry. - Food Research International 95: 68-81.

[35] Zyzak, D. V., Sanders, R. A., Stojanovic, M., Tallmadge, D. H., Eberhart, B. L., Ewald, D. K., Villagran, M. D. (2003): Acrylamide formation mechanism in heated foods. Journal of Agricultural and Food Chemistry 51(16): 4782-4787. 